2012

\title{
Torture and the War on Terror: The Need for Consistent Definitions and Legal Remedies
}

Linda Carter

Pacific McGeorge School of Law, lcarter@pacific.edu

Follow this and additional works at: https://scholarlycommons.pacific.edu/facultyarticles

Part of the Criminal Law Commons, Human Rights Law Commons, and the International Law Commons

\section{Recommended Citation}

Carter, Linda, "Torture and the War on Terror: The Need for Consistent Definitions and Legal Remedies" (2012). McGeorge School of Law Scholarly Articles. 206.

https://scholarlycommons.pacific.edu/facultyarticles/206 


\title{
Torture and the War on Terror: The Need for Consistent Definitions and Legal Remedies
}

\author{
Linda Carter*
}

The last few years have brought forth images that will, unfortunately, stay with us for a long time - Abu Ghraib, waterboarding, extraordinary renditions, and torture memos from the Bush administration. The harm from these actions to individuals, to international relations, and to the law is still unfolding. But there has also been time to begin an evaluation of what went wrong, and what can be done within the United States and internationally to remedy and to prevent abuses in the future.

While the United States has made some progress on undoing the harm from the legal interpretations of the Bush administration (such as the McCain Amendment prohibiting cruel, inhuman, or degrading treatment or punishment and President Obama's renunciation of certain interrogation techniques), the legal remedies for torture within the United States remain rather limited.

Among other approaches, the convictions in Italy of American and Italian intelligence agents for an abduction that resulted in a rendition to Egypt are a significant and needed part of the accountability for torture. The mixture of Italian and American agents and three countries is also indicative of another important fact to keep in mind. Neither the war on terror nor torture respects borders. A multinational effort is essential to achieve accountability.

In this article, I will address two questions related to definitions and accountability. First, why is there a need for a consistent definition? One lesson from the Bush administration torture memos is the danger of differing definitions. This question will be explored by comparing the U.S. approach with that of the International Criminal Tribunal for the former Yugoslavia (ICTY). Other places to look for definitions include other national laws and international bodies monitoring torture issues. Some examples from those sources will also be discussed. The second question

* Professor of Law and Director, Legal Infrastructure and International Justice Institute, University of the Pacific, McGeorge School of Law. I would like to express my appreciation to Professors Fausto Pocar, Marco Pedrazzi, and Gabriella Venturini of the Scuola di Dottorato in Scienze Giuridiche, Dottorato in Diritto internazionale, Università degli Studi di Milano, where I first presented the thesis advanced here. I owe the genesis of the idea for this paper to Beth Van Schaack and Ron Slye, who raise the issue of the meaning of intent in their textbook. BETH VAN SCHAACK \& RONALD C. SLYE, ITERNATIONAL CRIMINAL LAW AND ITS ENFORCEMENT 583 (2d. ed. 2010). I would also like to thank my research assistants, Joanna Yum and Jamie Garrett, for their extensive work on this project. 
is: What are the current limitations on available remedies that impede consistent accountability for torture? In discussing this question, I will examine criminal and civil options in the United States and in the international criminal tribunals as examples of what we have and what we lack.

The first section will provide background information on the Convention Against Torture and Other Cruel, Inhuman or Degrading Treatment or Punishment, statutory law in the United States, and interpretations in the jurisprudence of the ICTY. The definitional differences will be explored, including the saga of the memos from the Bush administration. In particular, the discussion will focus on mens rea, which has not been analyzed in the same depth as the definition of torture, but which is a powerful element in accountability. The second section will explain howthe definitional differences create problems, with a focus on international relations and accountability. In the third section, criminal and civil accountability mechanisms and limitations on those vehicles will be explored. In addition, alternatives to criminal or civil actions directly based on torture will be examined. These include prosecutions for underlying or related conduct, such as kidnapping or aggravated assault. This section will conclude with observations about next steps to take toward greater consistency and accountability.

Two preliminary observations should be kept in mind as the issues are discussed. First, criminal prosecutions for torture arise in different types of crimes. National jurisdictions are likely to have a crime that is labeled "torture." In the international criminal tribunals, however, there is no independent crime of torture. Instead, torture may be punished as a crime against humanity or as a war crime. The acts that constitute torture might also be penalized in national jurisdictions as assault, maltreatment of prisoners, murder, and similar more common crimes. It is important to remember that, when we talk about "torture," there are multiple crimes that might cover the conduct. Secondly, it is essential that national courts play a strong role in prosecuting torture. There is no specialized international court for torture prosecutions. The international criminal tribunals are limited in jurisdiction, hearing relatively few cases. Moreover, as already indicated, the international criminal tribunals can prosecute torture only in the context of crimes against humanity and war crimes, each of which carry additional and more complicated elements than the basic crime of torture. National courts are further critical to civil remedies for torture. There is no international court that is charged with awarding damages for torture. There is, however, an international treaty with a statement of what constitutes torture, which is discussed in the next section. 


\section{DEFINITIONS OF TORTURE}

\section{A. The Convention Against Torture and Other Cruel, Inhuman or Degrading Treatment or Punishment}

The Torture Convention was opened for signature in 1984 and entered into force in 1987. The definition of torture from Article 1 has five key elements.

Torture means any act by which

1. (Harm): "severe pain or suffering, whether physical or mental,"

2. (Mens rea): "is intentionally inflicted on a person"

3. (Enumerated purposes): "for such purposes as obtaining from him or a third person information or a confession, punishing him for an act he or a third person has committed or is suspected of having committed, or intimidating or coercing him or a third person, or for any reason based on discrimination of any kind,"

4. (State action): "when such pain or suffering is inflicted by or at the instigation of or with the consent or acquiescence of a public official or other person acting in an official capacity."

5. (Except for lawful sanctions): Torture "does not include pain or suffering arising only from, inherent in or incidental to lawful sanctions."

Two parts of the definition are the focus of this article, harm (the meaning of severe physical or mental pain or suffering) and mens rea (the meaning of of "intentionally inflicted").?

1. Article I (1) provides in full:

For the purposes of this Convention, the term "torture" means any act by which severe pain or suffering, whether physical or mental, is intentionally inflicted on a person for such purposes as obtaining from him or a third person information or a confession, punishing him for an act he or a third person has committed or is suspected of having committed, or intimidating or coercing him or a third person, or for any reason based on discrimination of any kind, when such pain or suffering is inflicted by or at the instigation of or with the consent or acquiescence of a public official or other person acting in an official capacity. It does not include pain or suffering arising only from, inherent in or incidental to lawful sanctions.

Convention against Torture and Other Cruel, Inhuman or Degrading Treatment or Punishment, Dec. 10, 1984, 1465 U.N.T.S. 85 [hereinafter Torture Convention].

2. Highly relevant to any discussion of torture, but beyond the scope of this article, is 
The Convention plays a highly significant role in the development of national definitions of torture. The United States and 149 other countries are parties to the Torture Convention. ${ }^{3}$ As is typical with regard to human rights treaties, the United States attached reservations and understandings to its ratification of the Convention, and the federal statute adopted to implement the Convention, took into account a key reservation and a key understanding.

\section{B. The Definition of Torture in the United States ${ }^{4}$}

Differences in definition can arise if the language of the statute is different from the Torture Convention. Differences can also arise if the identical language is interpreted in different ways. The experience of the United States is an example of both ways of deviating from other definitions.

Comparing the key elements of the U.S. federal criminal statutory definition with the key elements listed above in the Convention, we find the following limitations in the statute:

the Torture Convention's stand on conduct that is less than torture, but constitutes cruel, inhuman, or degrading treatment or punishment. Unfortunately, there is no definition of that concept, nor is there the same obligation to criminalize or provide compensation. The Convention states that that each State Party shall "undertake to prevent in any territory under its jurisdiction other acts of cruel, inhuman or degrading treatment or punishment which do not amount to torture as defined in article 1." This is clearly an area calling for future development, but at a minimum, there should be compliance with the requirements related to torture itself.

3. See Torture Convention, http://treaties.un.org/Pages/ViewDetails.aspx?src=UNT SONLINE\&tabid=2\&mtdsg_no=IV-9\&chapter=4\&lang=en\#Participants.

4. When ratifying the Torture Convention, the United States attached two key provisions that limit its reach. The first is a reservation stating that cruel, inhuman, or degrading treatment or punishment includes only "the cruel, unusual and inhumane treatment or punishment prohibited by the Fifth, Eighth, and/or Fourteenth Amendments to the Constitution of the United States." This is important, but not the focus of this article. The more pertinent limitation is the understanding regarding the definition of torture.

5. The complete definitions contained in the federal torture statute, 18 U.S.C. $\$ 2340$ (2006), are as follows:

(1) "torture" means an act committed by a person acting under the color of law specifically intended to infliet severe physical or mental pain or suffering (other than pain or suffering incidental to lawful sanctions) upon another person within his custody or physical control;

(2) "severe mental pain or suffering" means the prolonged mental harm caused by or resulting from-

(A) the intentional infliction or tbreatened infliction of severe physical pain or suffering;

(B) the administration or application, or threatened administration or application, of mind-altering substances or other procedures calculated to disrupt profoundly the senses or the personality;

(C) the threat of imminent death; or

(D) the threat that another person will imminently he subjected to death, 
1. (Harm): Limitation on mental harm.

Severe mental pain or suffering means prolonged mental harm from

- Intentional or threatened infliction of severe physical pain or suffering

- Use of mind-altering substances calculated to disrupt profoundly the senses or the personality

- Threat of imminent death, or

- Threat that another person will imminently suffer death, severe harm, or mid-altering substances.

2. (Mens rea): An act "specifically intended" to inflict the required harm.

3. (Enumerated purposes): No change.

4. (State action): The act is committed "by a person acting under the color of law" and "upon another person within his custody or physical control."

5. (Except for lawful sanctions): "other than pain or suffering incidental to lawful sanctions"

The two most critical comparisons between the federal torture statute and the language of the Torture Convention involve the phrases "severe mental pain or suffering" and "specifically intended." In order to understand the questions generated by this language, it is important to consider the so-called "torture memos" promulgated during the Bush administration, where the definitions stand today, and a comparison with the jurisprudence of the ICTY.

severe physical pain or suffering, or the administration or application of mind-altering substances or other procedures calculated to disrupt profoundly the senses or personality; and

(3) "United States" means the several States of the United States, the District of Columbia, and the commonwealths, territories, and possessions of the United States. 


\section{Definitions of Torture: A Comparison of the United States and the ICTY on the Meaning of Severe Harm and Intent}

\section{The meaning of "severe [physical] pain or suffering"}

After $9 / 11$ and the seizure of individuals in Afghanistan, issues arose regarding interrogation techniques. In a series of memos, lawyers in the Justice Department set forth their legal opinions of the reach of international law and the meaning of torture.

In a memorandum prepared during the Bush administration in 2002 under the authority of Assistant Attorney General Jay Bybee (the "Bybee memo"), severe physical pain or suffering was defined as damage that rises to "the level that would ordinarily be associated with a sufficiently serious physical condition or injury such as death, organ failure, or serious impairment of body functions." This definition would exclude many forms of physical harm, such as beatings that are not quite as serious as imminent death, waterboarding, or electrocution that does not threaten death. In comparison to the ICTY's definition, it is highly limited in what is included as sufficient harm for torture.

The ICTY has explicitly rejected the standard in the Bybee memo. ${ }^{7}$ The defense in Prosecutor v. Brdjanin had argued that the standard in the Bybee memo was customary international law. The Court rejected this standard and defined severe physical pain or suffering in a much broader way, stating that "the objective severity of the harm inflicted must be considered, including the nature, purpose, and consistency of the acts committed. Subjective criteria, such as the physical or mental condition of the victim, the effect of the treatment and, in some cases, factors such as the victim's age, sex, state of health, and position of inferiority will also be relevant in assessing the gravity of the harm. Permanent injury is not a requirement for torture; evidence of the suffering need not even be visible after the commission of the crime." held that rape is per se torture. ${ }^{9}$ Although the U.S. definition in the Bybee memo was extreme, the meaning of severe physical harm in the U.S. has edged closer to the ICTY's. Even before President Bush left office, his Administration had backtracked on the incredibly limited definition of physical pain or suffering related to organ failure. A 2004 memo, written

6. Memorandum from Jay S. Bybee, Dep't of Justice Office of Legal Counsel, to Alberto R. Gonzales, Counsel to the President, Standards of Conduct for Interrogation under 18 U.S.C $\$ \$ 2340-2340$ A (Aug. 1, 2002), at 6, available at http://www.justice.gov/olc/ docs/memo-gonzales-aug2002.pdf [hereinafter Bybee Memorandum].

7. Prosecutor v. Brdjanin, Case No. IT-99-36-A, Appeals Judgment, IIII244-248 (April 23, 2007).

8. Id. $\$ 242$.

9. Prosecutor v. Kunarac, Case No. IT-96-23 \& 23-1A, Appeals Judgment, 乌111 (June $12,2002)$. 
by Acting Assistant Attorney General Daniel Levin in the Office of Legal Counsel, clarified that "severe" does not include only "excruciating and agonizing pain or suffering." According to the memo, it means "a condition of some extended duration or persistence as well as intensity." This definition presumably brought the United States closer to the intended meaning of the Convention and to the ICTY's interpretation."

More developments were to follow that also moved the U.S. closer to the general definition. As soon as President Obama took office, he issued an executive order rescinding all of the earlier memos and declaring that the U.S. Army Field Manual standards for interrogation would apply. ${ }^{12}$ As of today, waterboarding is prohibited, as are: ${ }^{13}$

Forcing the detainee to be naked, perform sexual acts, or pose in a sexual manner.

Placing hoods or sacks over the head of a detainee; using duct tape over the eyes.

Applying beatings, electric shock, burns, or other forms of physical pain.

Using military working dogs.

Inducing hypothermia or heat injury.

Conducting mock executions.

Depriving the detainee of necessary food, water, or medical care.

With the reversion back to the Army Field Manual, the U.S. understanding of severe physical pain or suffering seems in line with the meaning given the phrase by other sources such as the U.N. Special

10. Memorandum from Daniel Levin, Acting Asst. Att'y Gen., to James B. Comey, Deputy Att'y Gen., Legal Standards Applicable Under 18 U.S.C. \$\$ 2340-2340A (Dec. 30, 2004), available at http://www.justice.gov/olc/18usc23402340a2.htm [hereinafter Levin Memorandum].

11. J. Herman Burgers \& Hans Danelius, The United Nations Convention Against TORTURe: A HandBoOK ON THE CONVENTION Against TORTURE and Other Cruel, InHLMAN or Degrading Treatment or PUnishment 44, 117 (1988) (drafters considered, but rejected, language that would have required a greater degree of pain or suffering, such as "extreme pain or suffering" or "systematic" pain or suffering).

12. Ensuring Lawful Interrogations, Exec. Order No. 13,491, 74 Fed. Reg. 4,893 (Jan. 22, 2009). A special task force was also created and asked to provide recommendations. The task force essentially found that the Army Field Manual was correct law. Press Release, U.S. Dep't of Justice. Special Task Force on Interrogations and Transfer Policies Issues Its Recommendations to the President (Aug. 24, 2009), available at http://www.justice. gov/opa/pr/2009/August/09-ag-835.html.

13. Army Field Manual 2-22.3: Human Intelligence Collector Operations, at 5-75 (Sept. 6, 2006), available at hitp://library.enlisted.info/field-manuals/series-1/FM2_22.3/FM 2-22.3.pdf. 
Rapporteur and cases from the European Court of Human Rights (ECHR) and the Human Rights Committee (HRC).

For example, according to the Special Rapporteur, torture includes "beatings; extraction of nails, teeth, etc.; burns; electric shocks; suspension; suffocation; exposure to excessive light or noise; sexual aggression; administration of drugs in detention or psychiatric institutions; prolonged denial of rest or sleep; prolonged denial of food; prolonged denial of sufficient hygiene; prolonged denial of medical assistance; total isolation and sensory deprivation; being kept in constant uncertainty in terms of space and time; threats to torture or kill relatives; total abandonment; and simulated executions.","+

The Human Rights Committee has found torture existed with "beatings, electric shocks to the genitals, mock executions, deprivation of food and water, and the "thumb press" and also in cases of "systematic beatings, electroshocks, burns, extended hanging from hand and/or leg chains, repeated immersion in a mixture of blood, urine, vomit and excrement ('submarino'), standing for great lengths of time, and simulated executions or amputations amounted to torture."15

Similarly, in cases brought under the Alien Tort Statute (ATS) and the Torture Victims Protection Act (TVPA), U.S. courts have found that allegations state a cause of action for torture when there are threats of imminent death, severe beatings and Russian roulette; ${ }^{16}$ being held without notification of charges for 27 days, beaten severely, stripped of clothing, and forced to witness the sexual assault of a friend that resulted in hemorrhaging: ${ }^{17}$ and a combination of being held in unsanitary conditions, chained, blindfolded, little clothing, poor food, and threats of death. ${ }^{18}$

Consequently, while the variant definition of severe physical pain or suffering in the torture memos received major attention in the media and in the academic literature, today the U.S. interpretation is essentially consistent with the meaning in the ICTY cases and other sources. Instead, the U.S. is presently more divergent with the meaning of severe mental pain or suffering and especially with the meaning of specifically intended.

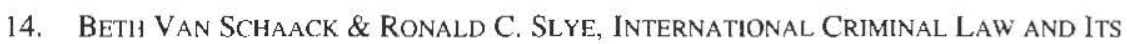
ENFORCEMENT 563 (2d. ed. 2010) (quoting Report of the Special Rapporteur on Torture, U.N. Doc. No. E/CN.4/1986/15, \1119(1986)).

15. Prosecutor v. Kvočka, Case No. IT-98-30/1-T, Judgment, भII46 (Nov. 2, 2001) (citing to decisions of the Human Rights Committee in cases involving Zaire Uruguay, and Bolivia).

16. Mehinovic v. Vuckovic, 198 F. Supp. 2d 1322 (N.D. Ga. 2002) (judgment for Bosnian Muslim plaintiffs against Bosnian Serb officer under ATS and TVPA for physical and mental torture).

17. Doe v. Qi, 349 F. Supp. 2d 1258 (N.D. Cal. 2004) (default judgment entered for Chinese and foreign individuals as plaintiffs under TVPA; however, recommendation was for declaratory relief only due to act of state doctrine).

18. Surrette v. Islamic Republic of Iran, 231 F. Supp. 2d. 260, 264 (D.D.C. 2002) (CIA officer Buckley died in captivity after such mistreatment). 


\section{The meaning of "severe [mental] pain or suffering"}

The definition of severe mental pain or suffering in the U.S. statute is limited in two ways. First, the U.S. added in the adjective "prolonged." Secondly, the U.S. statute, like the understanding attached to the ratification of the Convention, refers to severe mental pain or suffering caused by one of four events, described earlier, involving threat of severe physical harm or infliction or threat of severe physical pain or suffering, use of mind-altering substances, or threats of imminent death, or threats that another person will be subjected to similar mistreatment. Neither of these limitations is present in the jurisprudence of the ICTY.

The key question is whether the more limited definition would make a difference in application. The answer is possibly not in many situations. One of the four categories is "the intentional infliction or threatened infliction of severe physical pain or suffering," which would presumably cover many situations. On the other hand, mental pain or suffering must be "prolonged," which could preclude a finding of torture if there is no continuing psychological trauma from a method such as waterboarding or electrocution. Moreover, it is worth asking whether rape would be included as torture under this definition as interpreted by the United States. Rape might not necessarily be the result of a threat or infliction of severe physical pain or death. It is not clear that the act of rape itself would be viewed as severe physical pain or suffering under this definition.

In contrast, rape clearly would be torture under the ICTY jurisprudence. In Prosecutor v. Kunarac, the ICTY Appeals Chamber stated: "Sexual violence necessarily gives rise to severe pain or suffering, whether physical or mental, and in this way justifies its characterization as an act of torture."19 Thus, the limitations in the U.S. definitions could be a source of difference with the ICTY or other nations that do not have similar restrictions on mental harm.

Even if the U.S. definitions are closer now to the ICTY's, the lesson of the torture memos is the potential for differential meanings of severity of harm and resulting difference in application. An even more striking area for differential applications of the meaning of torture occurs with regard to the mens rea required to find a violation.

\section{The meaning of "specifically intended"}

The U.S. statute, again tracking the understanding that the U.S. attached to the Convention, provides that torture is committed when the perpetrator "specifically intended" the severe pain or suffering. This is different

19. Prosecutor v. Kunarac, Case No. IT-96-23 \& 23-1A, Appeals Judgment. I150 (June 12, 2002). 
wording from the Convention, which uses the phrase "intentionally inflicted." Note that this is a different issue than whether the intentional infliction of pain or suffering is done for the purpose of obtaining confession, punishment, intimidation, coercion, or discrimination - the purposes stated in the Torture Convention and in some national statutes. Here, the issue is the mens rea to commit the act of inflicting severe pain or suffering.

The question that arises is what happens if the accused intends the action that causes the severe harm, but does not subjectively intend that level of harm? This could occur when the victim reacts more severely than anticipated. For example, suppose the interrogator electrocutes the victim, expecting that the victim will feel in pain and highly uncomfortable, but not expecting that the person will suffer severe pain or die from his injuries. Or suppose that the accused intends to rape the victim, but does not intend or know that the victim will have long-lasting mental dysfunction as a result. Under the U.S. definition, these individuals would arguably have a defense based on the mens rea required.

In the early Bush administration memo, the position was clear that persons without a specific intent to inflict severe pain or suffering would not be guilty of torture. While evidence of knowledge in criminal law is often strong circumstantial evidence of intent, the 2002 Bush administration memo took the position that knowledge was insufficient. ${ }^{20}$ In the later Levin memo, it is unclear whether there was any lessening of this understanding. The 2004 memo examined specific intent, and indicated that "it would not be appropriate to rely on parsing the specific intent element of the statute to approve as lawful conduct that might otherwise amount to torture." The Levin memo referred to the distinction made in the 2002 Bybee memo between the severe harm as the "precise objective" of the defendant and where the defendant "act[s] with knowledge that such pain "was reasonably likely to result from his actions." In a footnote, the memo states that the Office of Legal Counsel "[does] not reiterate that test here." 21 Beyond this somewhat cryptic rejection of the Bybee memo, however, the Levin memo does not clearly indicate that knowledge is sufficient to satisfy the element of "specifically intended." The Levin memo merely indicates that a person acting in "good faith" that his conduct would not be torture has neither the "specific intent" nor "knowledge or notice" that the conduct would result in severe pain or suffering. ${ }^{22}$ The memo does not clearly repudiate the earlier Bybee memo understanding of mens rea.

The issue whether knowledge or notice is a sufficient mens rea is highly significant if the perpetrator is acting with awareness but not the conscious

20. Bybee Memorandum, supra note 6, at 3 .

21. Levin Memorandum, supra note 10, at n.27.

22. Levin Memorandum, supra note 10. 
purpose to achieve the harm. For example, if there are multiple perpetrators involved in shocking a prisoner with electricity, one perpetrator might know what is occurring and participate in some way, and yet not specifically intend the result of severe pain or suffering. This perpetrator would satisfy a knowledge standard, but would not likely be found to possess specific intent. It is unclear from the Levin memo whether or not such a perpetrator is guilty of torture. The Obama administration has yet to clarify where it stands on this issue and, in the meantime, U.S. courts have been interpreting the standard to require the higher mens rea.

In contrast, the ICTY has clearly stated that intent means "a perpetrator intended to act in a way which, in the normal course of events, would cause severe pain or suffering, whether physical or mental, to his victims." ${ }^{23}$ Presumably under this definition, the person electrocuting or raping an individual would meet the intent requirement. ${ }^{24}$

The ICTY's definition is a better interpretation of the Convention because the Convention's language separates the requirement of severe harm from the statement that it must be "intentionally inflicted." The legislative intent also supports the ICTY's interpretation. The legislative history of the Convention shows that the drafters wanted to exclude negligence or accident, not the lesser gradations of a subjective mens rea. ${ }^{25}$ This is further evident from the rejection of a higher mens rea. The United States had wanted the higher mens rea of "deliberately and maliciously" as the mens rea for inflicting the harm. This was rejected in the drafting.

Despite the likelihood that the U.S. definition is at odds with the language and meaning in the Convention, the U.S. did attach an understanding with the "specifically intended" language and U.S. courts are using the narrower mens rea in immigration removal or deportation cases. The federal courts are fairly uniform in finding that a "specific intent to inflict severe pain or suffering" is necessary to a finding of torture. For example, in January 2010, in Cherichel v. United States, the United States Court of Appeals for the Eighth Circuit affirmed the specific intent interpretation in a case involving a Haitian national who claimed that he would be subject to torture in a Haitian prison because of the prison conditions of lack of hygiene, lack of food and water, severe overcrowding, being detained indefinitely, and in this individual's specific case, being identified as an "American" because he had spent most of his life in the

23. Prosecutor v. Kunarac, Case No. IT-96-23 \& 23-1A. Appeals Judgment, \$I153 (June 12, 2002).

24. See also Gail H. Miller, Defining Torture, Floersheimer Center Occasional Paper \# 3, at I3 (2005), available at http://www.cardozo.yu.edu/cms/uploadedFiles/FLOERSHEIMER/ Defining \%20Torture.pdf (describing intent requirement of the ECHR as shifting the burden of proof to the government, creating a presumption of intent).

25. Burghirs \& Danelius, supra note 11, at 118 (1988): MANFrED NowaK \& ElizabeTH Mcarthur, The United Nations CONVENTION Against Torture: A COMMENTARy 74 (2008). 
United States. ${ }^{26}$ The petitioner was seeking to preclude his removal to Haiti on the basis of the Torture Convention. The Court found that there was insufficient evidence that the Haitian authorities would "specifically intend" to inflict severe pain and suffering on the person even though the severe harm might in fact be imposed. The courts interpret "specific intent" to mean an intent to achieve the result - in this case, the severe pain and suffering. An intent to commit the act of imprisoning the person under these conditions with the foreseeable effect of severe pain and suffering is insufficient under this definition. The court further noted specifically that knowledge that the severe pain and suffering would occur was insufficient. ${ }^{27}$

Under the ICTY definition of intent, however, it is likely that the Haitian situation would be torture, since incarcerating a person in a prison under those conditions would be an intentional act, the normal consequence of which is going to be severe harm.

The interpretation of "specifically intended" could be less significant, and the conclusion of torture would mirror the ICTY's conclusion, if the underlying acts of torture are particularly horrific. In another recent case in the Third Circuit, the court reversed a decision of the Board of Immigration Appeals, finding that a Chinese citizen of Korean ancestry would be subject to torture if returned to China. ${ }^{2 *}$ The petitioner, Jinyu Kang, was named in an arrest warrant along with two others in China for assisting North Korean refugees who had illegally entered China. Kang presented evidence that the other two had been subjected to beatings, partial suffocation from bags over their heads, sleep deprivation, forced kneeling or forced hanging off the ground, electrocution, and other mistreatment. Moreover, an American who was detained in China for 48 months described observing similar mistreatment of prisoners. Kang's own son, who had been interrogated about his mother's whereabouts after she fled China, was abused by sleep deprivation, slapping, and hair pulling. The Third Circuit rejected the federal government's arguments that Kang had failed, as in Cherichel, to prove specific intent. Here, the Court stated Kang had proved that she would more likely than not be subjected to the same brutality as her two accomplices, and that the abuse would be for the "purpose of causing her severe pain and suffering. ${ }^{29}$ The Court went even further, chastising the

26. Cherichel v. Holder, 591 F.3d 1002 (8th Cir. 2010). cert. denied, 131 S. Ct. 74 (2010). See also Villegas v. Mukasey, 523 F.3d 984 (9th Cir. 2008) (finding that, even if conditions in Mexican mental institutions were inhumane, petitioner failed to show that authorities specifically intended the harm).

27. Cherichel, 591 F.3d at 1011 .

28. Kang v. Attorney General, 611 F.3d 157 (3rd Cir. 201()).

29. Id. at 166-167. See also Cole v. Holder, 659 F.3d 762, 774 (9th Cir. 2011) (remanding for determination of whether Honduran offieials would intentionally withhold necessary medical treatment because petitioner was tattooed with gang insignia); Eneh v. Holder, 601 F.3d 943 (9th Cir. 2010) (remanding for determination of whether petitioner had established that Nigerian officials would specifically intend to deprive him of necessary 
federal government for seeking to send Kang back to China when the evidence of torture was so clear. The Court stated:

It is disappointing, even shocking, that the government fails to acknowledge that the evidence is not only strongly in Kang's favor, but, indeed, compels the conclusion that she will likely be tortured.

An attorney representing the United States "carries a double burden.",30

It may be that the meaning of specific intent is open to new interpretation. While not directly addressed in the executive orders that repudiated the Bush memos and substituted the Army Field Manual, there is a clear signal that the U.S. is moving towards a more generally accepted understanding of torture. Given the varied definitions of specific intent within U.S. law, it would be possible to construe the phrase to mean that the individual specifically intended the act that constituted the severe harm (e.g., electrocution, rape, breaking bones), but did not have to intend subjectively the severe nature of the harm. It should be of concern that, with a more narrowly defined mens rea, the U.S. definitions will continue to be more limited in covering acts than the ICTY definition and more limited than what was likely intended by the Torture Convention.

Especially with regard to mental, rather than physical, harm, the narrow view of the mens rea of specific intent could prevent a torture conviction for many actions that in fact cause long term mental harm, but where the perpetrator claims that he or she did not consciously desire that result. For example, even if the act of rape constituted severe physical or mental pain or suffering under the U.S. definition, a perpetrator could possibly exculpate himself by demonstrating that he did not consciously intend that result.

Under the ICTY's jurisprudence, the mens rea would in all likelihood be met because the perpetrator intended the act and, in the normal course of events, such act would cause severe pain or suffering.

Putting aside the United States for a moment, will the International Criminal Court (ICC) assist in creating more consistency? There are presently 121 nations that are parties to the Rome Statute. Each of those states is likely to ensure eventually that its definitions of crimes are comparable to the ICC's definitions." If the ICC has that impact now on

medications due to discrimination against persons with HIV medical conditions).

30. Id. at 167 .

31. Note, however, that presently, there is significant variation among national definitions of torture. See Julianne Harper, Defining Torture: Bridging the Gap Between Rhetoric and Reality, 49 SANTA CLARA L. REV. 893, 914-920 (2009) (describing variations in domestic definitions, such as a failure to define torture at all. differences in the meaning of severe, and the absence or presence of a state action requirement). 
121 states and is likely to have such an influence on more in the future as more states become parties, it is useful to consider how the ICC defines the mens rea for torture.

Torture can be the underlying act for either a crime against humanity or a war crime. For a crime against humanity of torture, the mens rea is intentional conduct, since torture is defined in that manner. Torture as a crime agairst humanity requires the "intentional infliction" of harm. ${ }^{32}$ War crimes are not defined with a mens rea for the infliction of the harm. ${ }^{33}$

32. Article 7 (1) (f), Statute of the International Criminal Court, Rome, art. 7 (2) (e), July 17, 1998, 2187 U.N.T.S. 3, U.N. Doc. A/Conf.183/9 [hereinafter Rome Statute]. The crime against humanity of torture consists of the following elements:

1. The perpetrator inflicted severe physical or mental pain or suffering upon one or more persons.

2. Such person or persons were in the custody or under the control of the perpetrator.

3. Such pain or suffering did not arise only from, and was not inherent in or incidental to, lawful sanctions.

4. The conduct was committed as part of a widespread or systematic attack directed against a civilian population.

5. The perpetrator knew that the conduct was part of or intended the conduct to be part of a widespread or systematic attack dirccted against a civilian population.

International Criminal Court, Elements of Crimes, available at http://www.icc-cpi.int/ NR/rdonlyres/336923D8-A6AD-40EC-AD7B-45BF9DE73D56/0/ElementsOrCrimes Eng.pdf.

33. There is a requirement of an awareness of the factual circumstances of the armed conflict and the status of the victims as protected persons for war crimes, but that is not the same as the inens rea with regard to the harm. The war crime of torture is defined in the Elements of Crimes as:

Article 8 (2) (a) (ii)-1 War crime of torture

Elements

1. The perpetrator inflicted severe physical or mental pain or suffering upon one or more persons.

2. The perpetrator inflicted the pain or suffering for such purposes as: obtaining information or a confession, punishment, intimidation or coercion or for any reason based on discrimination of any kind.

3. Such person or persons were protected under one or more of the Geneva Conventions of 1949.

4. The perpetrator was aware of the factual circumstances that established that protected status.

5. The conduct took place in the context of and was associated with an international armed conflict.

6. The perpetrator was aware of factual circumstances that established the existence of an armed conflict.

Elements of Crimes, supra note 32. There are a couple of other key variations between torture as a crime against humanity and torture as a war crimc. No specific purpose is required for a crime against humanity of torture, but the specific purposes of obtaining a confession, punishment, intimidation, coercion, or discrimination are required for war crimes of torture. An additional difference between torture as a crime against humanity and torture as a war crime is that the victim must be in the custody or under the control of the accused for a crime against humanity. but not for a war crime. 
Under the ICC statutory scheme, however, if there is no identified mens rea, the statute provides that the default mens rea for crimes is "intent and knowledge." ${ }^{\text {it }}$ Moreover, the general provisions of the Elements of Crimes include a statement that when a "value judgment," such as regarding "severe" is an element, it is not generally necessary to establish that the perpetrator made this judgment. This probably means that the perpetrator would not himself or herself have to specifically intend the severe harm; rather there would be an intent or knowledge mens rea with regard to the act and the consequence would be the severe harm. If the interpretation goes this route, the ICC's definition would not require a specific intent regarding the harm and, instead, would be virtually identical to the ICTY's approach. If states, even just the states parties, adopt the definitions of the ICC, that would be a significant number of states in the world without a specific intent limitation on the meaning of torture. ${ }^{35}$

\section{The PROBLEM OF DIFFERING DEFINITIONS}

The contrast between the U.S. statute and the ICTY decisions is indicative of a problem in definition and application. The mens rea, in particular, may result in opposite conclusions in a given situation. Although the prohibition of torture is viewed as customary international law, there are no specific examples in the Convention of what constitutes torture and the U.S. restrictions demonstrate that there are differences in understanding what qualifies as torture.

34. The General Introduction to the Elements of Crimes provides:

2. As stated in article 30 , unless otherwise provided, a person shall be criminally responsible and liable for punishment for a crime within the jurisdiction of the Court only if the material elements are committed with intent and knowledge. Where no reference is made in the Elements of Crimes to a mental element for any particular conduct, consequence or circumstance listed, it is understood that the relevant mental element, i.e., intent, knowledge or both, set out in article 30 applies. Exceptions to the article 30 standard, hased on the Statute, including applicable law under its relevant provisions, are indicated below.

3. Existence of intent and knowledge can be inferred from relevant facts and circumstances.

4. With respect to mental elements associated with elements involving value judgement, such as those using the terms "inhumane" or "severe," it is not necessary that the perpetrator personally completed a particular value judgement, unless othcrwise indicated.

Elements of Crimes, supra note 32.

35. The ICC could, of course, have an impact of establishing definitions different from the Convention. For example, one difference between the ICC definitions and the Convention is that no involvement by a state is required for either a crime against humanity or war crime of torture under the ICC. 
It is appropriate to ask whether we need consistent definitions. The answer is that the ramifications of different understandings of what constitute torture could be extensive. For example, the Convention prohibits extradition if an individual faces a risk of torture. Torture issues also arise in deportation or removal proceedings. As noted above, the U.S. courts are analyzing specific intent as a necessary element of torture in removal proceedings. Questions are likely to arise in the future whether a state, such as the United States, violates the Convention if it extradites to a country where torture occurs under one definition but not under the definition of the sending state. The same issue pertains in removal proceedings. The United States appears to be returning individuals to countries in which the U.S. courts acknowledge severe harm will occur but in which there is insufficient evidence of a "specific intent" to impose it. While arguably consistent with the U.S. understanding of torture, this application is, without question, at odds with the ICTY's definition. How should the compliance of the United States with the Torture Convention be assessed if, under the more widely-accepted definition, the United States is removing individuals to a country in which they will be tortured?

Another reason to be concerned with differing definitions is that torture often involves multiple states and possibly the need for multinational action. As a consequence, international relations and bilateral or multilateral actions or decisions will be affected if there is no agreement on the definition. For example, the case involving Abu Omar in Italy poses such a problem. He was abducted from Italy and sent to Egypt where he was allegedly tortured. Both American CIA and Italian intelligence agents were parties to the abduction and rendition. In a recent decision, an Italian court convicted $23 \mathrm{CIA}$ agents and 3 Italian agents of kidnapping in connection with tbe case. ${ }^{3 .}$ If the case had been the subject of actual torture proceedings, whose standard should govern? Under whose definition should a decision be made to act to prosecute the perpetrators? The U.S. standard? $?^{37}$ The Italian standard? The Egyptian standard? $?^{38}$ A related issue

36. Manucla D'Alcssandro \& Daniel Flynn, Italy Convicts Former ClA Agents in Rendition Trial, REUTERS, Nov. 4, 2009, available al http://www.reuters.com/anicle/id USTRE5A33QB20091104; Rachel Donadio, Italy Comicts 23, Most Working for C.I.A., of Abducting Muslim Cleric, N.Y. Tumfs. Nov. 5, 2009, at A15.

37. The United States, Italy, and Egypt are all partics to the Torture Convention.

38. The Egyptian constitutional provision spcaks only very generally, with no definition of torture:

Any person arrested or detained or his freedom restrained shall be treated in the manner that preserve his dignity. No physical or moral harm is to be inflicted upon him. He may not be detained or imprisoned except in places defined by laws organizing prisons.

If a confession is proved to have been made by a person under any of the aforementioned forms of duress or coercion, it shall be considered invalid and futile.

Constitution of 1971 (as amended on March 26, 2007), available at http:/www.apt.ch/ 
arises if collaborative action is necessary. Much time could be lost debating whether torture was at issue. Further, there is a danger of politics playing too large a role. Having one accepted interpretation would remove at least some of the politics from the situation.

Another major reason for consistency is accountability. ${ }^{39}$ A person committing the same acts in one state may be guilty of torture in one state but not in another. This does not promote a culture of accountability; instead it is a culture of fortuity as to where one commits the acts.

This is not to suggest that an overly broad interpretation is required, just a consistent one. An overly broad interpretation risks minimizing the seriousness of the offense.

\section{ACCOUNTABILITY FOR TORTURE}

The next question is, assumiug there is a workable, generally-accepted interpretation of torture, what are the means of accountability? The Torture Convention requires criminalizing torture, ${ }^{\text {t0 }}$ extradition or prosecution, ${ }^{41}$ and compensation for victims. ${ }^{42}$ It should be noted that states are not required to

index.php?option=com_k2\&view=item\&layout=item\&id=819\&Itemid=266\&lang=en.

39. For further reasons for consistency in definitions, see David LUBAN, Julie R. O'Sullivan \& David P. Stewart, International and Transnational Criminal Law 1093-1094 (2010).

40. Article 5(1) provides:

Each State Party shall take such measures as may be necessary to establish its jurisdiction over the offences referred to in article 4 in the following cases:

(a) When the offences are committed in any territory under its jurisdiction or on board a ship or aircraft rcgistered in that State:

(b) When the alleged offender is a national of that State;

(c) When the victim is a national of that State if that State considers it appropriatc.

41. Article 7 provides:

1. The State Party in the territory under whose jurisdiction a person alleged to have committed any offence referred to in article 4 is found shall in the cases contemplated in article 5 , if it does not extradite him. submit the case to its competent authorities for the purpose of prosecution.

2. These authorities shall take their decision in the same manner as in the case of any ordinary offence of a serious nature under the law of that State. In the cases referred to in article 5, paragraph 2, the standards of cvidence required for prosecution and conviction shall in no way he less stringent than those which apply in the cases referred to in article 5 , paragraph 1.

3. Any person regarding whom proceedings are brought in connection with any of the offences referred to in article 4 shall be guaranteed fair treatment at all stages of the proceedings.

42. Article 14(1) states:

Each State Party shall ensure in its legal system that the victim of an act of torture obtains redress and has an enforceable right to fair and adequate 
implement universal jurisdiction; they must criminalize only offenses committed within their territory and when the alleged offender is a national of that state. The Convention suggests, but does not mandate, criminalizing torture when the victim is a national of the state. Clearly, a state could opt for broader coverage than this or even universal jurisdiction. The Convention is the minimum required, not the maximum. For civil remedies, the Convention requires an "enforceable right to fair and adequate compensation."

\section{A. Limitations on Remedies and Alternatives}

The question with regard to remedies for torture, whether criminal or civil, is whether they are effective or whether there are too many limitations on the remedies to make them a useful vehicle. In the United States, the criminal statute is almost unused and civil actions have significant limitations.

Limitations in criminal actions include jurisdiction and failure to use the statute. The federal statute limits the crime to acts outside the United States and provides for jurisdiction only if the alleged perpetrator is a U.S. national or, regardless of nationality, is present within the United States. ${ }^{44}$ In other words, the statute does not cover torture committed within the United States. It does, however, cover U.S. nationals who commit torture elsewhere in the world. The statute further has a broad reach in that there is also jurisdiction over anyone who committed torture outside of the United States, but is found within the United States.

Who could be prosecuted under this statute? Examples would include a U.S. soldier who tortures a detainee in a foreign country; a U.S. civilian

compensation, including the means for as full rehabilitation as possible. In the event of the death of the victim as a result of an act of torture, his dependants [sic] shall be entitled to compensation.

43. Id.

44. 18 U.S.C. $\$ 2340$ (a) (2006) provides:

As used in this chapter -

(a) Orfense. Whoever outside the United States commits or attempts to commit torture shall be fined under this title or imprisoned not more than 20 years, or both, and if death results to any person from conduct prohibited by this suhsection, shall be punished by death or imprisoned for any term of years or for life.

(b) Jurisdiction. There is jurisdiction over the activity prohibited in subsection (a) if -

(1) the alleged offender is a national of the United States; or

(2) the alleged offender is present in the United States, irrespective of the nationality of the victim or alleged offender.

(c) Conspiracy. A person who conspires to commit an offense under this section shall be subject to the same penalties (other than the penalty of death) as the penalties prescribed for the offense,

the commission of which was the object of the conspiracy. 
who interrogates detainees with torture in a foreign country; and a foreign national who has tortured people in his home country, but is present within the United States.

Who cannot be prosecuted under this statute? One example is anyone who commits torture within the United States. Another example would be a foreign national who commits torture in his home country and remains outside the United States. The latter example is not particularly disturbing as the person could undoubtedly be prosecuted somewhere else more easily. But the first one, a person who commits torture within the United States, seems odd not to be covered, especially since the Torture Convention requires criminalizing conduct that is torture and occurs within the state's own territory.

Apparently, the United States thought that torture occurring within the United States was covered by existing laws, such as murder, kidnapping, and similar crimes. ${ }^{45}$ While the acts underlying the torture may be punished with lesser crimes, the question in this context would be whether there are sufficient penalties for the lesser crimes. There is an additional question whether this gap affects international relations.

Another related issue is whether the criminal statutes are actually invoked. How often has the federal torture statute been used? One case in which there might have been probable cause to believe torture occurred was the abuse of prisoners at the Abu Ghraib prison in Iraq. The soldiers were not, however, prosecuted for torture. Instead, they were prosecuted under the Uniform Code of Military Justice (UCMJ) for crimes such as maltreatment of prisoners, assault, indecent acts, and dereliction of duty. One of the most responsible, Spc. Graner, was sentenced to 10 years in prison. ${ }^{46}$ Similarly, during the Vietnam War, Lt. Calley was not prosecuted for torture for crimes committed in My Lai, although he was prosecuted for murder. Regarding torture, however, the U.S. military has never prosecuted anyone under the torture statute, nor have they prosecuted anyone for a war crime of torture. One of the primary reasons for this is that the statutory

45. The federal statute was amended in 2004 to clarify that "outside the United States" included places such as Guantanamo Bay. Afghanistan, and similar areas that are under the control of the United States, but outside its territorial boundaries. See John Sifton, United States Military and Central Intelligence Agency Personnel Abroad: Plugging the Prosecutorial Gaps, 43 HARV. J. ON LEGIS. 487, 500-50I (2006).

46. United States v. Graner, 69 M.J. 104, 105 (C.A.A.F. 2010). Graner was convicted of maltreatment of persons subject to his orders, conspiracy, assault, indecent acts and dereliction of duty. Pfc. Lynndie England, shown in a number of the photographs, was sentenced to three years. Others reccived sentences ranging from 6 months to $81 / 2$ years. Still others received a discharge or a reprimand. See Josh White, Resenvist Sentenced to 3 Years for Abu Ghraih Abuse, Pfc. England Apologizes for Photographed Mistreatment, Says Superior and Lover 'Used' Her, WASH. POST, Sept. 28, 2005, at A12.; David Dishneau, Abu Ghraih Officer's Sentence: Reprimand. WASH. POST, Aug. 29, 2007, available at http://www.washingtonpost.com/ wpdyn/contentarticle/2007/08/29/AR2007082901038.htm. 
scheme of the UCMJ is set up with a preference to prosecute for an enumerated offense. War crimes and torture are not enumerated offenses and would have to be incorporated through an assimilation provision. ${ }^{47}$ There are likely to be legal challenges to the use of an assimilated crime as that provision is only to be invoked if enumerated offenses do not apply.

In civilian courts in the United States, only one prosecution has ever occurred for torture under the federal statute. Chuckie Taylor, the son of Charles Taylor, was convicted in federal court in Florida in October of 2008 for torture in Liberia and sentenced in December 2009 to 97 years in prison. ${ }^{48}$ Consequently, it would be fair to say that criminal prosecutions for torture, rather than the underlying acts, are close to nonexistent.

Civil actions, on the other hand, are more common in the United States, although these actions, too, have various limitations. The civil actions are most often brought under the Alien Tort Statute (ATS) and the Torture Victim Protection Act (TVPA). The ATS is limited to foreign nationals as plaintiffs. although the defendants can be either foreign or U.S. nationals. ${ }^{49}$ The "torts" are limited to violations of the law of nations or a treaty of the United States. The courts have long considered torture such a "tort," so the nature of the cause of action is not a limitation, although the limitation on who can be a plaintiff does constitute a significant restriction. The TVPA has broader coverage as anyone, including U.S. citizens, may bring an action. However, unlike the ATS, under which U.S. officials can be sued, the TVPA authorizes actions only against those operating under color of law of a foreign nation. ${ }^{\text {so }}$

47. Article 134 of the U.C.M.J., 10 U.S.C. $\$ 934$ (2006), provides:

Though not specifically mentioned in this chapter, all disorders and neglects to the prejudice of good order and discipline in the armed forces, all conduct of a nature to bring discredit upon the armed forces, and crimes and offenses not capital, of which persons subject to this chapter may be guilty, shall be taken cognizance of by a general, special or summary court-martial. according to the nature and degree of the offense, and shall be punished at the discretion of that court.

48. United States v. Belfast, 611 F.3d 783, 801 (11th Cir. 2010), cert. denied, $131 \mathrm{~S}$. Ct. 1511 (2011); see United States v. Emmanuel, Order on Defendant's Motion To Dismiss the Indictment, 2007 WL 2002452 (S.D. Fla. 2007), for a description of the charges and factual allegations. The alleged torture included "repeatedly burning the victim's flesh with a hot iron, forcing the victim at gunpoint to hold scalding water, hurning other parts of the victim's flesh with scalding water, repeatedly shocking the victim's genitalia and other body parts with an electrical device, and rubbing salt into the victim's wounds. while the victim was within the Defendant's custody and physical control ...."

49. 28 U.S.C.A. $\$ 1350$ (2006) provides: "The district courts shall have original jurisdiction of any civil action by an alien for a tort only, committed in violation of the law of nations or a treaty of the United States."

50. The Act, which is codified as a note to 28 U.S.C. $\$ 1350$ (2006), provides:

(a) Liahility. - An individual who, under actual or apparent authority, or color of law, of any foreign nation -

(1) subjects an individual to torture shall, in a civil action, be liable for damages to that individual; or 
Typical actions under the ATS and TVPA include foreign citizens bringing actions against foreign individuals or governments. For example, Bosnian Muslim citizens brought an action under ATS and TVPA against Karadzic, the Bosnian Serb political leader who is now on trial at the ICTY, for genocide, war crimes, and crimes against humanity. ${ }^{51}$ Another example is a case in which Somali citizens have brought an action against Samantar, the former first vice president and minister of defense in Somalia, for torture and extrajudicial killings during his time in office. ${ }^{52}$ There are also ATS actions brought by foreign citizens against U.S. officials, such as Guantanamo detainees suing the Secretary of Defense and other officers. Cases against U.S. officials are often dismissed, however, on the basis of qualified immunity. ${ }^{53}$

As a side note that is of interest in examining definitions of torture, the definition under the TVPA provides that torture occurs when the acts are "intentionally inflicted" for one of the enumerated purposes. ${ }^{54}$ This is the

(2) subjects an individual to extrajudicial killing shall, in a civil action, be liable for damages to the individual's legal representative, or to any person who may be a claimant in an action for wrongful death.

(b) Exhaustion of remedies. - A court shall decline to hear a claim under this section if the claimant has not exhausted adequate and available remedies in the place in which the conduct giving rise to the claim occurred.

(c) Statute of limitations. - No action shall be maintained under this section unless it is commenced within 10 years after the cause of action arose.

51. A default judgment was entered against Karadzic, with a jury award of $\$ 4.5$ billion in compensatory and punitive damages. Doe v. Karadzic, 192 F.R.D. 133 (S.D.N.Y. 2000) (judgment); Center for Constitutional Rights, http://ccrjustice.org/ourcases/past-cases/doe-v.karadzic (discussion of case and amount); Doe v. Karadzic, No. 93 Civ. 878, judgment (S.D.N.Y. Oct. 5, 2000) (damage awards), available at http:/ccrjustice.org/files/Karadzic Judgment.pdf.

52. Samantar v. Yousuf,, 130 S. Ct. 2278 (2010).

53. See Padilla v. Yoo, 678 F.3d 748 (9th Cir. 2012) (action brought by U.S. citizen based on U.S. Constitution and Religious Freedom Restoration Act (RFRA); dismissed on qualified immunity grounds); Rasul v. Myers, 563 F.3d 527 (D.C. Cir. 2009) (action brought by four British nationals under ATS, Bivens, and RFRA; ATS counts dismissed for failure to exhaust remedies under Federal Tort Claims Act against a U.S. official acting within scope of employment; Bivens counts dismissed on grounds of qualified immunity; RFRA claims dismissed on grounds plaintiffs are not protected persons under the Act); see also Ali v. Rumsfeld, 649 F.3d 762 (D.C. Cir. 2011) (Iraqi and Afghani civilians brought action against Rumsfeld and other officials under 5th and 8th amendments, Bivens, and the Geneva Conventions; charges dismissed due to qualified immunity and, for Bivens claim, "special factor" of obstructing national security policy).

54. The TVPA defines torture as follows:

(1) the term 'torture' means any act, directed against an individual in the offender's custody or physical control, by which severe pain or suffering (other than pain or suffering arising only from or inherent in. or incidental to, lawful sanctions), whether physical or mental, is intentionally inflicted on that individual for such purposes as obtaining from that individual or a third person information or a confession, punishing that individual for an act that individual or a third person 
same language that is in the Torture Convention. The modifier "specifically" is not part of the definition of torture under the TVPA. No cases to my knowledge have yet explored this difference or its significance. ${ }^{S 5}$ Thus, even within one country - the United States - the definitions are different.

Despite the availability of ATS and TVPA civil actions, there have not been many successful cases under these statutes. ${ }^{56}$ One of the issues that hinders cases is unresolved questions surrounding official immunity. Many of the ATS/TVPA cases involve actions against former government officials who orchestrated the torture of citizens. These officials routinely claim immunity from civil actions. Although the U.S. Supreme Court recently held in Samantar v. Yousuf that the Foreign Sovereign Immunities Act (FSIA) covers states, not individuals, the Court remanded the ATS/TVPA case for resolution of issues of individual immunity under the common law and customary international law. ${ }^{57}$ Individual immunity for sitting or former government officials is an area in which there are significant unresolved issues, including whether immunity exists for international crimes, such as torture, if done in an official capacity, and whether a former official is entitled to immunity ${ }^{58}$

has committed or is suspected of having committed, intimidating or coercing that individual or a third person, or for any reason based on discrimination of any kind; and

(2) mental pain or suffering refers to prolonged mental harm caused by or resulting from -

(A) the intentional infliction or threatened infliction of severe physical pain or suffering;

(B) the administration or application, or threatened administration or application, of mind altering substances or other procedures calculated to disrupt profoundly the senses or the personality;

(C) the threat of imminent death; or

(D) the threat that another individual will imminently be subjected to death, severe physical pain or suffering, or the administration or application of mind altering substances or other procedures calculated to disrupt profoundly the senses or personality.

55. For example, the jury instructions from one case simply state "intentionally inflict" - the language of the TVPA statute. Jury Instructions at 9. Romagoza Arce v. Garcia, 434 F.3d 1254 (11th Cir. 2006), available at http:/www.cja.org/downloads/Romagoza_Jury_ Instructions_242.pdf. See also supra note 53 (providing citations on qualified immunity).

56. For an unofficial list of cases, see http://viewfromll2.com/2009/11/11/alien-tortstatute-cases-resulting-in-plaintiff-victories/.

57. Samantar v. Yousuf,. 130 S. Ct. 2278, 2292-2293 (2010). On remand, the district court found. on the basis of a determination submitted to the court by the U.S. State Department, that Samantar's common law immunity claim was no longer before the court. Yousuf v. Samantar, 2011 WL 7445583 (E.D. Va. Feb. 15, 2011). For the determination by the State Department that was submitted to the court, see Statement of Interest of the United States of America, available at http:/www.cja.org/downloads/Samantar_Stmt_of_Interest. pdf.

58. See discussion in David P. Stewart, Samantar v. Yousuf, Foreign Official Immunity Under Common Law, vol. 14 Issue 15, June 14, 2010, available at http://www. 
Another issue that precludes civil accountability is the "state secrets" doctrine. Pursuant to this doctrine, either the case itself may be barred ${ }^{5 y}$ or evidence may be privileged and not admissible. ${ }^{60}$ The underlying reasoning is that the government may invoke "state secrets" if national security would be threatened by revealing the information to the public. The Ninth Circuit Court of Appeals has defined state secrets as whether "from all the circumstances of the case, that there is a reasonable danger that compulsion of the evidence will expose . . . matters which, in the interest of national security, should not be divulged." ${ }^{61}$ In a recent case, the Ninth Circuit applied this standard to an action against an American corporation, Jeppesen Dataplan, Inc., that had allegedly assisted the government in extraordinary renditions that resulted in torture. ${ }^{62}$ The plaintiffs alleged torture in Morocco, Egypt, and Afghanistan through the arrangement between Jeppesen and the CIA. The plaintiffs were an Egyptian national, an Italian national, an Iraqi national who was a legal resident of the United Kingdom, and two Ethiopian nationals, one of whom was a legal resident of the United Kingdom. They were purportedly handed over to the Americans by the Swedish, Pakistani, Gambian, and Jordanian governments. The torture allegations include severe beatings, electrocution, sleep and food deprivation, threats of sexual abuse, unceasing loud noise such as screams, and the pouring of stinging liquid into open wounds. The court held that plaintiffs' case should be dismissed under the state secrets doctrine. While not deciding if the case should be categorically barred on the basis of the subject matter of the case, the court held that application of the evidentiary version of the doctrine required dismissal under the circumstances of this case. Even though some of the plaintiffs' evidence was public, the court found that the case could not go forward "without creating an unjustifiable risk of divulging state secrets." ${ }^{63}$

The legal questions surrounding immunity and state secrets illustrate two of the possible limitations on the effectiveness of civil actions for accountability in the United States. If the avenues for accountability are limited in the United States, what about in other international and national forums? As mentioned earlier, the international criminal courts are not a venue in which many cases can be adjudicated. There are, however, cases that were brought or are ongoing through universal jurisdiction in France, Germany and Spain against American government officials. ${ }^{64}$ However, the

asil.org/insights100614.cfm.

59. Totten v. United States, 92 U.S. 105, 107 (1876).

60. United States v. Reynolds, 345 U.S. 1, 11 (1953).

61. Mohamed v. Jeppesen Dataplan, Inc., 614 F 3.d 1070, 1081 (9th Cir. 2010), cert. denied, 131 S. Ct. 2442 (2011).

62. Id.

63. Id. at 1087 .

64. Katherine Gallagher, Universal Jurisdiction in Practice: Efforts To Hold Donald 
cases in France and Germany did not go forward. In France, there was a determination that former Secretary of the Defense Rumsfeld would have immunity. ${ }^{65}$ There was also a decision not to proceed with a criminal investigation in a 2004 case in Germany involving Iraqi detainees in Iraq, largely out of deference to letting the U.S. proceed first. A second case, brought in 2006 in Germany involving 11 Iraqi detainees and one Saudi detainee at Guantanamo, similarly resulted in a decision not to pursue an investigation largely on the basis that there was no connection with Germany and the accused were not likely to be in Germany. ${ }^{66}$

Spain appears to be an exception in that two cases, both recently instituted in 2009, are pending. One case is brought against six Bush administration lawyers (including Bybee and Yoo), ${ }^{67}$ The other case was brought by four former Guantanamo detainees, one of whom is a Spanish citizen and another who is a longtime Spanish resident. ${ }^{68}$ There is recent legislation that limits the reach of Spanish jurisdiction to cases that involve a Spanish national or a suspect who is in Spanish territory before the investigation commences, but it does not affect these cases. ${ }^{69}$

While universal jurisdiction is admirable, clearly there are political and resource issues that each country must assess, especially when there is no connection with nationals or the territory of that country. That is why actions as in the Italian prosecution are particularly essential. In that action, there was a clear connection to Italy since the abduction occurred on Italian soil. $^{79}$ The commencement of the acts leading to torture was in Milan. Italy

Rumsfeld and Other High-Level United States Officials Accountable for Torture, 7 J. INT'L CRIM. JUST. 1087,1109 (2009).

65. Id. at 1111 .

66. Id. at 1102,1105 .

67. The others being sued are Alberto Gonzales, who was the Attorney General; Douglas Feith, who was the former Undersecretary of Defense for Policy; William Haynes, who was the Defense Department's general counsel; and David Addington, who was Vice President Cheney's chief of staff. This case was stayed in April 2011 and referred to the U.S. Department of Justice; that decision, however, is being appealed to the Spanish Supreme Court. The proceedings are described on the website of the Center for Constitutional Rights (CCR), http://ccrjustice.org/spain-us-torture-case.

68. Gallagher, supra note 64 , at 1113 . The case is proceeding, following a decision in January 2012 that the court has jurisdiction. CCR website, supra note 67.

69. Andrew Morgan, Spain Lower House Votes To Limit Reach of Universal Jurisdiction Statute, JURIST, June. 25, 2009, http://jurist.Iaw.pitt.edu/paperchase/2009/06/ spain-lower-house-votes-to-limit-reach.php; Thomas Catan, Spain Is Moving To Rein In Its Crusading Judges; Congress Aims To Limit Human-Rights Inquiries, Such as the One Probing Torture Allegations at Guantanamo Bay, WaLL ST. J., May 20, 2009, at A6; Soeren Kern, Spain Changes Tack on Universal Jurisdiction, Brussels JourNAL, June 1, 2009. available at http://www.brusselsjournal.com/node/3945.

70. See Francesco Messineo, Extraordinary Renditions' and State Obligations To Criminalize and Prosecute Torture in the Light of the Abu Omar Case in Italy. 7 J. INT'L CRIM. JUST. 1023, 1023 (2009) (the action in Italy was the crime of "sequestro di persona" which Messineo translates as abduction, although he also translates the indictment as "kidnapped"). 
could have, however, turned a blind eye to these actions because the actual torture occurred in Egypt. It is highly significant that an Italian court took this step to hold the individuals accountable for the actions that resulted in torture.

The various cases, from the United States, France, Germany, Spain, Italy, and the international criminal courts point out how inconsistent our attempts are at regulating and providing accountability for torture. The combination of varying definitions and inconsistent enforcement should be of concern in the actual implementation of the Torture Convention. Certainly, there are criminal prosecutions of individuals for torture, either as a crime in and of itself or as a form of a war crime or a crime against humanity. Criminal prosecutions also occur for the underlying conduct or related conduct, even if it is not denominated torture. The Italian case is an example of this with a prosecution for kidnapping. The typical courtmartial in the United States is another example where the prosecution is for maltreatment of prisoners or other similar crimes. There can be, however, great hesitation in prosecuting for torture. We have seen it with the Obama administration's reaction to whether or not to prosecute the interrogators or other officials under the Bush administration. ${ }^{71}$ The dismissal of ATS/TVPA cases on immunity or state secrets grounds derails accountability efforts. Similarly, the dismissal of actions under universal jurisdiction, as in France and Germany, indicates a reluctance to go forward with the cases.

\section{B. Steps for the Future}

There is a need for clarification of the definitions and an imperative for an international effort at coordinating both prosecution and compensation cases for torture. Limitations on civil and criminal remedies include jurisdictional, definitional, and political restrictions. There is inconsistency in criminal prosecutions in national courts and in the availability of civil remedies. While the ICC may provide some leadership in this area once they have cases alleging torture as a war crime or a crime against humanity, it is clear that most criminal adjudications of torture will occur in national courts. Moreover, there may be reasons to differentiate definitions in criminal and civil contexts and the ICC cannot provide guidance on civil actions. Further research is needed to document standards for criminal and

71. Gallagher, supra note 64, at 1099 (Holder ordered a preliminary investigation and special counsel was appointed August 24,2009. As of July 16, 2010. the special counsel had yet to issue a report. See http://topics.nytimes.com/top/reference/timestopics/organizations/c/ central_intelligence_agency/cia_interrogations/index.html?sep=1\&sq=investigation $\% 20 \mathrm{ClA} \% 20 \mathrm{i}$ nterrogators \&st $=\mathrm{cse}$. 
civil cases of torture and to track outcomes of civil cases. There also may be differentials in state as opposed to individual accountability standards.

At the outset of this article, I posed two questions. The first question was why there is a need for greater consistency in the definition of torture. Although torture can occur within national boundaries, there is a transnational characteristic involved as perpetrators flee to other countries when they are deposed or uncovered and as states begin to coordinate efforts to combat torture. Additionally, there are international bodies that either adjudicate or monitor torture. Without a common understanding of what constitutes torture, international efforts in prosecution, extradition, and regulation are likely to be obstructed or delayed. It is surely a lesson of the recent past in the United States that definitions do matter. The definitional issues of "severe physical or mental pain or suffering" and "intent" are examples of how different definitions can be and what a difference those definitions make in conclusions about torture.

The second question was what impediments exist to effective remedies for torture. Impediments include definitional issues, but also jurisdictional and other limitations, such as immunity. There is a need to revisit the efficacy of our criminal and civil actions on national levels to make those responsible accountable for torture or the Convention does not stand for much. The need for greater national procedures for investigating, prosecuting, and providing reparations for torture is a clear theme in the UN Special Rapporteur on Torture's report from February $2010 .^{72}$ The report noted:

Although 146 States are party to the Convention against Torture and Other Cruel, Inhuman or Degrading Treatment or Punishment, most Governments have failed to effectively implement its provisions. Despite the obligation to criminalize torture and prosecute perpetrators of torture under different types of jurisdiction, only very few torturers have been brought to justice worldwide. Impunity continues to be one of the main factors in widespread torture. Despite the obligation to provide victims of torture with an effective remedy and adequate reparation for the harm suffered, only a very small number of victims of torture are able to enjoy this right in the country responsible for inflicting the torture. $^{73}$

72. Report of the Special Rapporteur on torture and other cruel, inhuman or degrading treatment or punishment, Manfred Nowak, to the United Nations Human Rights Council, 9 February 2010, available at http:/www2.ohchr.org/english/bodies/hrcouncil/docs/13 session/AHRC-13-39.pdf.

73. Id. at 19 . 
While national remedies are essential, it is also clear that torture goes beyond borders, and that a reconsideration of definitions and remedies is needed for the sake of those subject to torture and for the sake of international cooperation in combating torture. 